\title{
PERAN MISYKAT \\ (MICRO FINANCE SYARI'AH UNTUK MASYARAKAT) DPU(DOMPET PEDULI UMAT) DAARUT TAUHID DALAM PENGENTASAN KEMISKINAN
}

\author{
Nur Fatoni ${ }^{1}$
}

\begin{abstract}
Abstrak
Kemiskinan di kota Semarang masib tinggi dan program penegntasan kemiskinan yang dilaksanakan pemerintah kota belum menuai hasil yang mengembirakan. ${ }^{2}$ Secara umum Umat Islam adalah bagian dari anggota masyarakat yang miskin dan bodoh, meskipun tidak ada data penghasilan perkapita (GNP) khusus umat Islam. Dimana ada program pengentasan kemiskinan umat Islam menjadi sasarannya, disamping umat agama lainnya. Hal ini menunjukkan Gambaran Islam in action berbeda dengan Islam in book.

Penelitian ini mengambil permasalahan bagaimana konsep Micro Finance Syariat untuk masyarakat (Misykat) DPU Daarut Tahubid serta bagaimana respon anggota Misykat terhadap realisasi program misykat DPU Daarut Taubid cabang semarang?
\end{abstract}

Keyword : Masyarakat miskin, micro finance

\section{Pendahuluan}

Ajaran Islam tentang keseimbangan dan keadilan ekonomi adalah memerintahkan derma dalam berbagai bentuk, supaya harta tidak beredar di kalangan orang kaya saja. ${ }^{3}$ Wujud derma dalam al-Qur'an berupa zakat, infaq dan shadaqah. Ada pula pembagian pendapatan yang diperoleh dari hasil kegiatan bersama yang terorganisir oleh negara, seperti fai' (upeti) dan ghanimah (pampasan perang). ${ }^{4}$

Miskin dalam konteks fiqh dibedakan dengan faqir. Keduanya mewakili kelompok dbu'afa' (lemah/papa). Faqir adalah kelompok yang tidak memiliki harta dan mata pencaharian. Kalaupun ia punya keduanya tidak mencukupi kebutuhannya. Misalnya ia punya 2 dinar kebutuhannya 10 dinar.

${ }^{1}$ Dosen Fakultas Ekonomi dan Bisnis Islam IAIN Walisongo Semarang

${ }^{2}$ Kompas, Jum'at, 27 juni 2007

${ }^{3}$ Q.S: 59:7

4 Nur Fatoni, Zakat, Infaq, dan Shadqah dalam perspektif al-Qur'an, (penelitian dipa fak.Syari'ah 2007), hal.1-2. 
Miskin adalah kelompok yang memiliki harta dan mata pencaharian, namun belum mencukupi sepenuhnya kebutuhannya. Misalnya ia punya 7 dinar kebutuhannya 10 dinar. ${ }^{5}$

Zakat adalah salah satu rukun Islam, sebagaimana shalat, puasa dan haji. Kewajiban melaksanakan zakat bagi yang mampu nilainya sebanding dengan pelaksanaan ibadah lainnya. ${ }^{6}$ Hal ini berarti peribadatan seseorang yang mampu tidak sempurna manakala tidak membayar zakat. Zakat termasuk ibadah mabdhah (murni) yang memiliki fungsi sosial untuk pemerataan kekayaan supaya harta tidak hanya berputar di antara orang-orang kaya saja. ${ }^{7}$

Distribusi zakat berarti distribusi rizki. Zakat merupakan salah satu upaya meringankan beban hidup kaum lemah dan menciptakan pemerataan kesejahteraan hidup di dunia. Sistem distribusi zakat secara tepat kepada mustakbiq (kelompok yang berhak menerima zakat), model penentuan mustakbiq dan tata cara penyeluran serta pemberdayaannya adalah modal utama untuk menekan kesenjangan kelompok kaya miskin.

Mengacu pada konsep pendistribusian zakat yang berkesinambungan akan terjadi proses pengalihan kapital, keterampilan dan teknologi secara terarah dari kelompok kaya kepada kelompok miskin dan lemah. Distribusi zakat dalam konsep syara' (hukum Islam) menuntun amil (otorita administrasi dan pelaksana kegiatan pengenerima, pengumpul, pendistribusi dan pengelola zakat) untuk mengarahkan kebijakan distribusi bukan sebatas meringankan beban hidup kaum lemah sesaat pada momen keagamaan saja seperti hari raya idul fitri, tetapi sampai pada tingkat memenuhi kebutuhan pokok kaum lemah sepanjang hidupnya hingga mereka mampu. Dalam hal situasi dan kondisi memungkinkan amil memiliki tugas menjadikan kelompok lemah yang berposisi menjadi mustabiq (penerima zakat) berubah menjadi muzakki (pembayar zakat). ${ }^{8}$ Dibutuhkan seperangkat aturan hukum untuk memayungi kegiatan amil zakat dalam menjalankan tugas pemerataan kekayaan tersebut.

5 Taqiyuddin Abu bakar bin Muhammad, Kifayatul Ahyar, Juz.I, Dar al-Ihya' al-Kutub alArabiyah, hlm. 197.

${ }^{6}$ Al-Buhari, Jami' al Shabih Bukhari, Juz.1, Dar al-Fikr, t.th, hlm. 11.

7 Q.S. al-Hasr:7.

${ }^{8}$ Drs Saifuddin Zuhri, M.Ag, Zakat Kontekstual, CV. Bima Sejati, Semarang, 2000, hlm. 24-36. 
Di Indonesia payung hukum untuk pengelolaan zakat telah ada berupa UU no 38 tahun 1999 tentang pengelolaan zakat.

Salah satu Lembaga Amil Zakat yang merespon amanat Undangundang pengelolaan zakat untuk mendayagunakan zakat adalah Dompet Peduli Umat Daarut Tauhid. Program DPU DT. Ia memiliki model khusus yang berkaitan dengan pendayagunaan zakat, yaitu pemberdayaan zakat melalui lembaga Micro Finance Syari'ah untuk masyarakat (Misykat). Program Misykat didesain untuk memberi pinjaman modal kerja kepada kelompok faqir miskin yang telah memiliki usaha dan hasilnya belum mencapai nisab (batas minimal wajib zakat) 9. Pinjaman tersebut diberikan kepada anggota Misykat secara berkelompok dan dilakukan selama tiga tahap. Angsuran pinjaman dilakukan setiap pekan, bersama dengan tabungan-tabungan untuk kelompok Misykat maupun pribadi anggota Misykat.

Program Misykat dimaksudkan membina dan memandirikan anggota untuk menjadi muzakeki (pembayar zakat). Kegiatan yang dilakukan adalah pinjaman, tabungan, pembinaan mental spiritual dan menejemen bisnis. Kelengkapan organisasi yang dimiliki adalah koordinator Misykat, pembina majelis Misykat, ketua kelompok dan anggota. Melihat tujuan program yang berhubungan langsung dengan kelompok miskin, peneliti ingin menjelaskan peran DPU DT dalam pengentasan kemiskinan, khususnya di cabang Semarang. Arti penting penelitian ini adalah menunjukkan bentuk penerapan ajaran Islam untuk mendayagunakan zakat untuk kelompok miskin menjadi berdaya dan mandiri, melalui lembaga amil zakat.

\section{Permasalahan}

Berdasarkan latar belakang masalah di atas, peneliti membatasi kajian dalam penelitian pada beberapa permasalahan sebagai berikut:

1. Bagaimana konsep Micro Finance Syari'at untuk masyarakat (Misykat) DPU Daarut Tahuhid?

${ }^{9}$ Menurut peneliti lebih tepat jika dikatakan, modal dan hasil usahanya belum mecapai nisab. Karena yang diwajibkan zakat adalah modal perdagangan bukan hasil perdagan saja.

Volume V/Edisi 1/Mei 2014 
Peran Misykat Daarut Taubid dalam Mengentaskan Kemiskinan

2. Bagaimana respon anggota Misykat terhadap realisasi program misykat DPU Daarut Tauhid cabang semarang?

3. Bagaimana relasi antara Misykat DPU Daarut Tauhid cabang Semarang dengan pengentasan kemiskinan?

\section{Pembahasan}

Penelitian ini menggunakan pendekatan kwalitatif, data yang dibutuhkan berupa narasi tentang obyek yang diteliti. Metode pengumplan data yang dipakai adalah dokumentasi dan wawancara. Data dianalisis dengan diskriptif analisis dengan pengkajian dan pengkatagorian model konsep yang dipakai, relasi aksi dengan pengentasan kemiskinan dan perbandingan konsep dan pelaksanaan.

Problem yang membelenggu Kelompok miskin sehingga mereka tidak berdaya untuk keluar dari situasi miskin adalah tidak bemodal cukup dan tidak mandiri. Kekurangan dan ketergantungan pada modal menjadikan mereka tidak mampu mengembangkan usahanya. Menurut muhammad Yunus solusi yang diberikan Lembaga resmi dunia maupun pemerintah kurang efektif karena melihat kemiskinan secara global dengan program pengentasa kemiskinan yang global pula. Padahal yang diperlukan bagi mereka program yang benar-benar menyentuh mereka, yaitu pembinaan, permodalan dan jaringan usaha. Solusi untuk mereka memerlukan wadah berupa lembaga khusus. Pilihan yang memungkinkan adalah dalam bentuk lembaga keuangan. ${ }^{10}$ Lembaga keuangan bisa berupa bank atau non bank. Lembaga Keuangan bisa menjembatani kebutuhan modal kelompok miskin yang diperoleh dari kelompok kaya.

Dalam penelitian ini penulis mengambil data di DPU Daarut Tauhid cabang Semarang. Sumber informasi yang dituju adalah koordinator Misykat Dendi, beberapa pembina, yaitu: Rantini, Sari, Wahid, Saiful dan Munadi, dan beberapa anggota misykat.

\footnotetext{
63-65

${ }^{10}$ Muhammad Yunus, Bank kaum Miskin, terj. Irfan Nasution, Marjin Kiri, Depok, 2007, hlm.
} 
1. Konsep Misykat DPU DT

Program misykat adalah program pemberdayaan non pemerintah, terstuktur dan berkelanjutan. Misykat bukanlah amil zakat, tetapi merupakan organisasi mustakhiq (penerima zakat) yang menjadi perwakilan kelompok miskin. Sasaran yang dituju adalah kelompok miskin yang memiliki usaha mikro. Dalam tata organisasinya, misykat dikelola oleh koordinator misykat. Koordinator dibantu oleh pendamping majelis. Para anggota dipimpin oleh ketua kelompok. Beberapa kelompok bergabung menjadi satu majelis dan dipimpin oleh ketua majelis.

Program yang dijalankan berupa pemberian pinjaman modal (pembiayaan) secara bergulir dan bergilir serta pembinaan anggota. Pembinaan dilaksanakan sebelum pencairan pembiayaan dana bergulir sampai anggota mencapai tahap mandiri. Materi pembinaan meliputi menejemen usaha, kewirausahaan dan ibadah praktis.

Pembiayaan dana bergulit diberikan setelah anggota mendapat pembinaan awal selama enam sampai dua belas pekan (minggu), kurang lebih satu setengah sampai tiga bulan. Pembiayaan dana bergulir khusus untuk pengembangan usaha anggota. Jumlahnya disesuaikan dengan kemampuan dana misykat dan kebutuhan anggota. Pengguliran dilakukan selama tiga tahap, dengan pola 2-2-1. Artinya dalam satu kelompok ada lima anggota. Dana diberikan kepada dua orang, kemudian disusul dua orang dan terakhir satu orang.

Aqad pembiayaan dana bergulir tahap pertama adalah qardul hasan artinya anggota tidak menambah pokok pinjaman. Total angsuran dengan pokok pinjaman sama. Pokok diangsur selama enpat puluh sampai enam puluh pekan. Tahap kedua dan ketiga menggunakan aqad bagi hasil sesuai kesepakatan, atau marjin keuntungan yang disepakati. Penggunaan bagi hasil atau marjin keuntugan disesuaikan dengan penggunaan dana. Masa Pengembalian sama dengan tahap pertama. Setelah tahap ketiga anggota diharapkan telah mandiri. Dengan diberikan pinjaman modal kerja dan pembinaan selama tiga tahap, anggota diharapkan menjadi pengusaha yang efektif, efisien dan mandiri. 
Setiap ada pinjaman yang tidak lancar, kurang lancar atau macet, ditanggug oleh kelompok. Untuk mengatasi masalah tersebut, diberlakukan sistem tanggung renteng dalam kelompok dan tabungan yang meliputi tabungan kelompok, majelis, cadangan resiko dan masa depan. Langkah yang ditempuh oleh pendamping dan Koordinator dalam mengatasi pinjaman bermasalah adalah dengan cara-cara persuasif terprogram. ${ }^{11}$

2. Pelaksanaan program Misykat di DPU DT cabang Semarang

Program misykat mulai dilaksanakan di cabang semarang pada tahun 2006. Hal-hal yang terjadi di cabang Semarang, sebagai bentuk konkrit konsep misykat adalah :

1. Perihal Pelaksanaan program Misykat di DPU DT cabang Semarang. Ada yang baru dari panduan, yaitu: tahap pertama dan kedua dilaksanakan dengan akad qardul hasan. Sisitem Bagi hasil dilaksanakan pada tahap ketiga. Sedangkan di panduan tahap kedua diprogramkan bagi hasil. Pola pengelompokan tidak selalu lima orang dengan pola pengguliran 2-2-1. Di DPU DT cabang Semarang berprinsip tiga tahap penggiliran seperti konsep. Ada contoh di semarang, satu kelompok 11 orang. Penguliran dananya 4-4-3.

2. Gaji/honor koordinator dan pembina dari DPU DT cabang Semarang, bukan dari lembaga misykat. Misykat dinilai belum mampu menggaji. Sehingga gaji koordinator dan pembina ditanggung oleh anggaran operasional DPU Daarut tauhid cabang Semarang. Menurut konsep misykat adalah lembaga mandiri dan terpisah dari DPUDaarut tauhid. Peran DPU-Daarut Tauhid adalah memfasilitasi, membina dan mensuplai dana zakat secara periodik kepada misykat. Pengelolaan dana zakat yang telah diserahkan kepada misykat adalah menjadi tanggung jawab pengurus misykat.

${ }^{11}$ Ir. Iwan Rudi Saktiawan, M.Ag DKK, Panduan Operasional Strategi Pemberdayaan Program Misykat Dompet Peduli Umat Daarut Tauhid, DPU DT Press, Bandung, 2006. hlm. 5-99. 
3. Dana misykat diperoleh dari DPU DT sebesar Rp 3.000.000,- (tiga juta) setiap bulan, dan pengguliran dana disesuaikan dengan kemampuan keuangan DPU DT yang disetor kepada misykat. ${ }^{12}$

4. Pembinaan sebelum dana digulirkan dilakukan selama 8 pekan, sedangkan menurut panduan dimungkinkan antara 8 sampai 12 pekan.

5. Jumlah dana yang digulirkan untuk setiap anggota maksimal Rp 1.000.000,- (satu juta). Kebijakan ini diambil guna menyesuaikan dengan kebutuhan modal para anggota yang disesuaikan dengan kekuatan keuangan misykat..

6. Angsuran tahap pertama gelombang pertama 48 pekan, gelombang kedua 40 pekan, gelombang tiga 30 pekan. ${ }^{13}$

7. Jumlah anggota misykat 76 orang, umumnya perempuan. Mereka tidak membentuk kelompok tetapi langsung menjadi majelis. Ada enam majelis yang tersebar di enam kelurahan..$^{14}$ Adapun data anggota alam setiap kelompok, jumlah pinjaman yang diterima dan rekapitulasi anggota berdasarkan pendidikan dan usaha yang dijalankan adalah sebagai berikut:

Tabel 1

Data Anggota Misykat Hingga Mei 2008

\begin{tabular}{|c|c|c|c|}
\hline NO & $\begin{array}{c}\text { NAMA } \\
\text { ANGGOTA }\end{array}$ & ALAMAT TINGGAL & $\begin{array}{c}\text { JUMLAH } \\
\text { DANA }\end{array}$ \\
\hline \multicolumn{4}{|c|}{ MAJELIS: MAR'ATUSHOLIHAH, Kel. Jomblang, Kec. Candi Sari } \\
\hline 1 & Jumini & Jl. Tandang RT VI RW IX & Rp 500.000 \\
\hline 2 & Jumini & Jl. Tandang Selatan RT VI RW X & $\mathrm{Rp} \quad 200.000$ \\
\hline 3 & Lasmi & Jl. Tandang RT XI RW X & $\begin{array}{ll}\mathrm{Rp} & 500.000 \\
\end{array}$ \\
\hline 4 & Mening & Kp. Tandang RT XI RW X & $\begin{array}{ll}\mathrm{Rp} & 400.000 \\
\end{array}$ \\
\hline 5 & Romsiyah & Jl. Tandang RT IX RW X & Rp 200.000 \\
\hline 6 & Sri Nanik & Jl. Tandang RT IX RW X & $\begin{array}{ll}\mathrm{Rp} & 500.000\end{array}$ \\
\hline 7 & Suparjiyah & Kp. Tandang RT XI RW X & Rp 500.000 \\
\hline 8 & Tukiyem & Jl. Tandang RT VII RW X & Rp 350.000 \\
\hline 9 & Winarsih & Jl. Tandang RT IX RW X & Rp $\quad 400.000$ \\
\hline
\end{tabular}

12 Wawancara dengan Dendi koordiantor misykat DPU DT cabang Semarang, Jumat, 1 Agustus 2008

13 Wawancara dengan Rantini pembina misykat, ahad, 1 september 2008.

14 Wawancara dengan Dendi, Op.,Cit., Jum'at, 8 Agustus 2008 
Peran Misykat Daarut Taubid dalam Mengentaskan Kemiskinan

\begin{tabular}{|c|c|c|c|}
\hline 10 & Sri Rejeki & Jl. Tandang RT IX RW X & $\mathrm{Rp} \quad 410.000$ \\
\hline 11 & Mulyati & Jl. Tandang RT IX RW X & $\mathrm{Rp} \quad 500.000$ \\
\hline 12 & Titik Karsiyanti & Jl. Tandang RT IX RW X & $\mathrm{Rp} \quad 500.000$ \\
\hline \multicolumn{4}{|c|}{ MAJELIS: KHOTIDJAH, Kel. Bandarharjo, Kec. Semarang Utara } \\
\hline 13 & Masminah & Jl. Kalibaru Timur RT 4 RW 10 & Rp 500.000 \\
\hline 14 & Poniyem & Jl. Kalibaru Timur RT 4 RW 10 & $\mathrm{Rp} \quad 500.000$ \\
\hline 15 & Semi & Jl. Kalibaru Timur RT 6 RW 10 & $\mathrm{Rp} \quad 500.000$ \\
\hline 16 & Syamsurinah & Jl. Kalibaru Timur RT 2 RW 10 & $\mathrm{Rp} 700.000$ \\
\hline 17 & Tumini & Jl. Kalibaru Timur RT 2 RW 10 & $\mathrm{Rp} \quad 500.000$ \\
\hline \multicolumn{4}{|c|}{ MAJELIS: FATIMAH AZ ZAHRI, Kel. Kuningan, Kec. Semarang Utara } \\
\hline 18 & Fauziyah & Jl. Kerapu 7 RT 8 RW 2 & Rp 500.000 \\
\hline 19 & Karsiyati & Kp. Sodongan Jl. Kerapu Timur 30A & Rp 500.000 \\
\hline 20 & Kusmiyati & Brotojoyo Timur VII RT 06 RW 01 & Rp $\quad 500.000$ \\
\hline 21 & Rumiyati & Jl. Boom Lama Kp. Pabean & Rp $\quad 600.000$ \\
\hline 22 & Sujiyati & Jl. Kerapu Timur No. 5 & $\begin{array}{ll}\mathrm{Rp} & 500.000 \\
\end{array}$ \\
\hline \multicolumn{4}{|c|}{ MAJELIS: MUHAJIRIN, Kel. Sambiroto, Kec. Tembalang } \\
\hline 23 & Agus Supriyanto & Jl. Kencur III RT 08 RW VIII & $\mathrm{Rp} \quad 500.000$ \\
\hline 24 & Indah Puji Lestasi & Jl. Taman Sambiroto Timur & $\begin{array}{ll}\mathrm{Rp} & 500.000\end{array}$ \\
\hline 25 & Kasminah & Jl. Sambiroto XI RT 06 RW VII & $\begin{array}{ll}\mathrm{Rp} & 500.000\end{array}$ \\
\hline 26 & Mitro & Jl. Kunir 3 RT 3 RW 3 & Rp $\quad 500.000$ \\
\hline 27 & Nanad Jaenudin & Jl. Sambiroto XI RT 03 RW 07 & Rp 1.000 .000 \\
\hline 28 & Noklilah & Jl. Jahe III No. 310 RT 12 RW 08 & Rp $\quad 500.000$ \\
\hline 29 & Purnomo & Jl. Jahe III No. 311 RT 12 RW 08 & $\mathrm{Rp} \quad 500.000$ \\
\hline 30 & Raminah & Jl. Sambiroto X RT 04 RW 06 & Rp $\quad 500.000$ \\
\hline 31 & Sis Riyanto & Jl. Taman Sambiroto RT 12 RW 08 & Rp $\quad 500.000$ \\
\hline 32 & Sudarni & Jl. Berlian I Mangunharjo & Rp $\quad 500.000$ \\
\hline 33 & Sutiah & Jl. Cendana I RT I RW I & $\mathrm{Rp} \quad 500.000$ \\
\hline 34 & Titik Yulianti & Jl. Cendana I RT 01 RW 09 & Rp 1.000 .000 \\
\hline \multicolumn{4}{|c|}{ MAJELIS: BAITUSSALAM, Kel. Bandarharjo, Kec. Semarang Utara } \\
\hline 35 & Langgeng Widodo & Jl. Kalibaru Timur RT 02/10 & $\mathrm{Rp} \quad 750.000$ \\
\hline 36 & Moch Sodli & Jl. Lumba-lumba Raya RT 02/10 & Rp 1.000 .000 \\
\hline 37 & Mukaromah & Jl. Kalibaru Timur RT 06/10 & Rp 1.000.000 \\
\hline 38 & Munjaenah & Jl. Kalibaru Timur RT 02/10 & Rp 1.000 .000 \\
\hline 39 & Ngatono & Jl. Kalibaru Timur RT 02/10 & $\begin{array}{l}\text { Belum } \\
\text { digulirkan }\end{array}$ \\
\hline 40 & Paryono & Jl. Kalibaru Timur RT 03/10 & Rp 1.000 .000 \\
\hline 41 & Patmi & Jl. Kalibaru Timur RT 05/10 & Rp 1.000.000 \\
\hline 42 & Slamet Prihatin & Jl. Kalibaru Timur RT 06/09 & Rp 850.000 \\
\hline 43 & Subari & Jl. Kalibaru Timur RT 07/10 & Rp 1.000 .000 \\
\hline 44 & Sulastri & Jl. Lumba-lumba Raya RT 07/10 & Rp 750.000 \\
\hline 45 & Tanem & Jl. Kalibaru Timur RT 01/10 & $\mathrm{Rp} 1.000 .000$ \\
\hline \multicolumn{4}{|c|}{ MAJELIS: ISTIQOMAH, Kel. Bulu Lor, Kec. Semarang Utara } \\
\hline 46 & Hartinah & Jl. Mustokoweni Tengah III/340 RT 02/05 & \\
\hline 47 & Heni Susilowati & Jl. Banowati Tengah III/30, RT 04 RW 05 & \\
\hline 48 & Karsini & Jl. Palgunadi Utara 95, RT 01 RW 06 & \\
\hline
\end{tabular}




\begin{tabular}{|c|c|c|c|}
\hline 49 & Maryani & Jl. Banowati Tengah III/27, RT 04 RW 05 & \\
\hline 50 & Mujiati & Jl. Banowati Tengah V/32, RT 02 RW 05 & Rp $\quad 500.000$ \\
\hline 51 & Munatun & Jl. Mustokoweni Tengah 3, RT 02 RW 05 & Rp $\quad 600.000$ \\
\hline 52 & Nurwati & Jl. Banowati Tengah III/27, RT 04 RW 05 & Rp $\quad 800.000$ \\
\hline 53 & Samiah & Jl. Banowati Tengah I/49, RT 08 RW 05 & Rp $\quad 800.000$ \\
\hline 54 & Samiyem & Jl. Banowati Tengah III/20, RT 04 RW 05 & \\
\hline 55 & Sri Markijah & Jl. Banowati Tengah III/14, RT 04 RW 05 & \\
\hline 56 & Susiyah & Jl. Srikandi No. 340 RT 05 RW 02 & \\
\hline \multicolumn{4}{|c|}{ MAJELIS: AL IHSAN, Kel. Gabahan, Kec. Semarang Tengah } \\
\hline 57 & Abdul Rohman & Jl. Wot Gandul Baben No. 14 & \\
\hline 58 & Achmad Budiyono & Jl. Wot Gandul Baben No. 28 & \\
\hline 59 & Arif & Jl. Wot Gandul Baben No. 192A & \\
\hline 60 & $\begin{array}{l}\text { Giyadi Heri } \\
\text { Saputra }\end{array}$ & Jl. Wot Gandul Baben & \\
\hline 61 & Herry & Jl. Wot Gandul Baben No. 26 & \\
\hline 62 & Kasri & Jl. Wot Gandul Baben No. 192A & \\
\hline 63 & Moch Romzi & Jl. Wot Gandul Baben No. 29 & Rp 1.000 .000 \\
\hline 64 & Mujayani & Jl. Wot Gandul Baben No. 19 & \\
\hline 65 & Slamet & Jl. Wot Gandul Baben & \\
\hline 66 & Sukamto & Jl. Wot Gandul Baben No. 18 & Rp 1.000 .000 \\
\hline 67 & Sukarman & Jl. Wot Gandul Baben & \\
\hline 68 & Sukarno & Jl. Wot Gandul Baben & Rp 1.000.000 \\
\hline 69 & Suratno & Jl. Wot Gandul Baben & \\
\hline 70 & Suroto & J1. Wot Gandul Baben No. 33 & \\
\hline \multicolumn{4}{|c|}{ MAJELIS: AL AMIN, Kel. Dadapsari, Kec. Semarang Utara } \\
\hline 71 & $\begin{array}{l}\text { Diah Asri } \\
\text { Rahmaniah }\end{array}$ & Jl. Petek Kp. Umres Besar 90 RT 05 / 06 & \\
\hline 72 & Fatimah & Jl. Petek Kp. Umres Besar 89 RT 05 / 06 & \\
\hline 73 & Muriah & Kp. Bedas Selatan 126 I RT 10 RW 06 & \\
\hline 74 & Rochni & Jl. Bedas Selatan 110 RT 07 RW 06 & Rp 1.000 .000 \\
\hline 75 & Sulimah & Jl. Petek Bedas Selatan RT 08 / 06 No. 228 & \\
\hline 76 & Suminah & Jl. Dorang Bedas Selatan 126 I RT 10 / 06 & \\
\hline
\end{tabular}

\section{Grafik Tingkat Pendidikan Terakhir Anggota MISYKAT Dompet Peduli Ummat Daarut Tauhiid Cab. Semarang Periode Hingga Juni 2008}

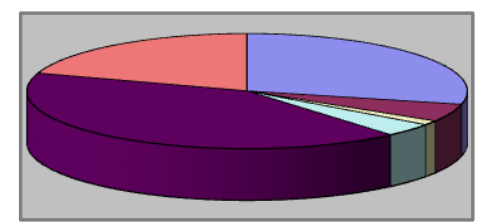

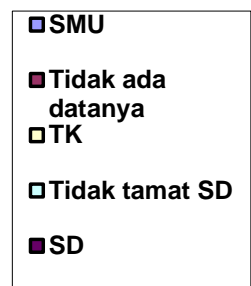


Peran Misykat Daarut Taubid dalam Mengentaskan Kemiskinan

Grafik Jenis Usaha Anggota MISYKAT Dompet

Peduli Ummat Daarut Tauhid Cab. Semarang

Periode Hingga Juni 2008

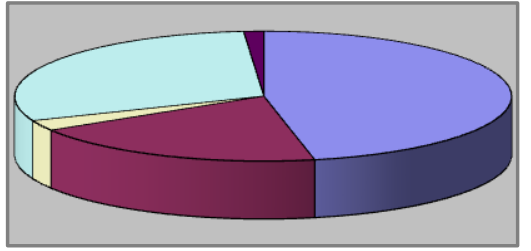

口Pedagang Makanan

口Pedagang Sayur

Mayur

口Jasa

口Pedagang lain-lain

Gratik Jenis Usaha Jasa Anggota MISYKAT DPU DT

Cabang Semarang Periode Hingga Juni 2008

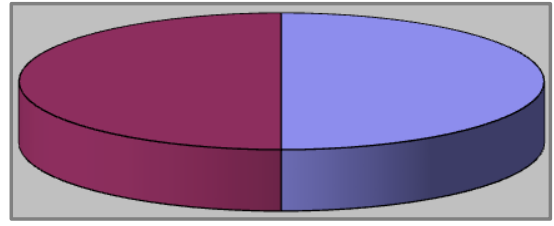

口Cuci pakaian (laundri

Grafik Jenis Usaha Lain-lain Anggota MISYKAT DPU DT Cabang Semarang Periode Juni 2008

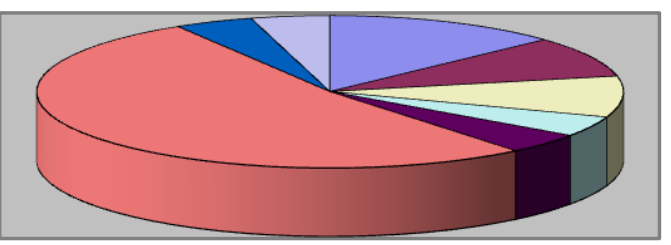

$\square$ Pertukangan \&

bangunan

口Benda pos

$\square$ Sepatu \& Sandal

口Koran

Grafik Jenis Usaha Makanan Anggota MISYKAT DPU DT Cabang Semarang Hingag Juni 2008

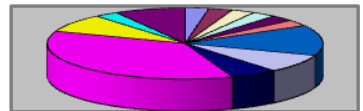

\begin{tabular}{|c|c|c|c|}
\hline 口Siomay & 口Kantin & 口Mie Ayam & 口Tahu Gimbal \\
\hline 口Bandeng Presto & $\square$ Soto & 口Kerupuk & 口Sate \\
\hline $\begin{array}{l}\text { EGorengan } \\
\text { 口Buah }\end{array}$ & 口Warung Nasi & 口Snack & 口Tahu Gimbal \\
\hline
\end{tabular}




\section{Grafik Jenis Usaha Sayur Mayur Anggota MISYKAT DPU DT Cabang Semarang Periode Hingga Juni 2008}

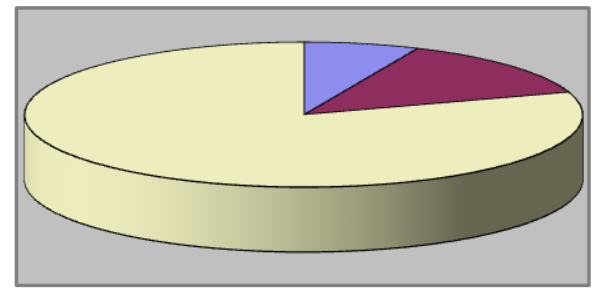

口Ayam Potong

口lkan Laut

口Sayuran

3. Respon anggota terhadap program miskat

Para anggota memberikan respon yang relatif sama terhadap program misykat. Mereka merasa terbantu dalam hal pendanaan untuk mengembangkan usahanya. Seperti yang dialami kelompok Istiqomah. Mereka berjumlah 11 orang. Mereka memiliki usaha yang sejenis, penjual bahan pokok. Tempat tinggal mereka berdekatan di kelurahan Bulu Lor kecamatan Semarang Barat kodya Semarang.. Jenis dagangan dan cara berdagang mereka beragam. Ada yang khusus bahan pokok kering seperti gula dan beras, ada pula yang menjual bahan makanan basah seperti sayur dan adapula yang menjual makanan siap saji. Umumnya mereka punya tempat dagang yang khusus, namun adapula yang berkeliling (jawa:ider). Mereka mengunakan dana misykat untuk menambah dagangan. Contoh konkrit awalnya anggota hanya mampu kulakan (membeli untuk dijual) lima kilo gula seminggu, dengan dana tersebut bisa meningkat 10 kilo. Akibatnya keuntungan mereka naik seiring dengan persediaan dagangan yang lebih beragam dan lebih banyak. ${ }^{15}$

Sebelum ikut program misykat mereka menggunakan pinjaman dari lembaga keuangan umum. Pinjaman tersebut terasa sulit didapatkan dan kurang cocok untuk mereka. Bunga dan jangka waktu pengembalian cukup tinggi dalam waktu relatif pendek. Persoalan lainnya yang dihadapi adalah pinjaman diterima tidak utuh karena telah dipotong biaya administrasi dll. Di sisi lain tidak ada pembinaan bisnis yang dilakukan, karena motifasi lembaga keuangan di luar misykat semata-mata bisnis jasa

15 Wawancara dengan anggota majelis istiqamah, Ahad, 7 September 2008. 
Peran Misykat Daarut Taubid dalam Mengentaskan Kemiskinan

keuangan. Lembaga tidak mau tahu problematika para peminjam. Meskipun jumlah dana misykat kecil max Rp 1.000.000,- (satu juta rupiah) mereka merasa diperhatikan, dilayani dan diberdayakan.

Keberadaan pembina sangat mendukung pelaksanaan program misykat. Kehadiran pembina membantu anggota dalam berhubungan dengan lembaga misykat. Peran pembina menjadikan anggota lebih maju. Kemajuan yang didapat berupa kesadaran pentingnya kemandirian dan dorongan keluar dari kemiskinan dengan jalan yang di ridloi Allah. ${ }^{16}$

Analisa konsep Misykat adalah sebagai berikut:

1. Analisa Konsep Misykat.

Dalam perspektif kelembagaan misykat tak ubahnya lembaga keuangan pada umumnya. Ia memiliki kegiatan funding (penggalian dana) dan landing (penyaluran dana). Dana misykat disuplai dari DPU DT dan pinjaman/ pembiayaan diberikan kepada kelompok miskin. ${ }^{17}$ Dalam hal ini misykat menjalankan fungsi intermediasi, menjembatani kelompok surplus dana dan kelompok kekurangan dana. Perbedaan mendasar misykat dengan lembaga keuangan lainnya adalah dari sisi kepemilikan lembaga dan sistem operasional yang dijalankan.

Misykat dimiliki oleh para anggota lembaga misykat itu sendiri. Misykat memiliki pensuplai dana dari pihak lain, yaitu DPU- Daarut Tauhid yang mana ia bukan pemilik misykat. Dalam hal tersebut misykat beda dengan model koperasi, dimana dananya berasal dari anggota. Misykat tidak menerima dana dari masyarakat secara langsung, tetapi melalui DPU Daarut tauhid. Hal tersebut membedakannya dengan lembaga perbankan yang bisa menerima langsung dana masyarakat.

Lembaga misykat menjadi penggulir dana kepada kelompok miskin. Ia tidak bebas menyalurkan dana. Operasionalisasi misykat mirip dengan grameen bank (bank kaum miskin) yang digagas

${ }^{16}$ Wawancara dengan anggota majelis fatimatuzzahro', senin, 8 September 2008.

${ }^{17}$ Ir. Iwan Rudi Saktiawan, M.Ag DKK,Op., Cit., hlm. 5-12. 
Muhammad Yunus dari Banglades. Melihat pola penggulirannya berdasarkan kelompok, penyaulrannya yang berurutan dalam satu kelompok dan sistem tanggung renteng dalam pengembalian pinjaman, antara misykat dan grameen bank yang digagas oleh Muhammad Yunus. Hal yang membedakan adalah pola pembinaan dengan sentuhan keagamaan. Misykat menggabungkan pengentasan kemiskinan harta dengan pengentasan kemiskinan ruhani para anggota. Ada misi ganda dalam program misykat, yaitu mengentaskan anggota dari kemiskinan harta dan ruhani. Perbedaan yang lain adalah sumber dana misykat yang diperoleh dari zakat yang dikumpulkan DPU Daarut tauhid. Grameen bank dananya diperoleh dari pemerintah. Ada usaha pemberdayaan zakat yang nyata pada misykat, dan tidak ada pada grameen bank. Menurut peneliti, konseptor misykat melakukan kegiatan ATM, yaitu amati, tiru dan modifikasi terhadap konsep grameen bank milik Mmuhammad Yunus. Tindakan tersebut peneliti nilai sebagai tindakan cerdas dalam menerapkan ajaran Islam zakat dipadu dengan sistem lembaga keuangan khusus.

2. Analisa respon anggota Misykat.

Anggota misykat telah menjadi in group ( bagian) lembaga misykat. Para anggota tidak hanya sebagai peminjam atau obyek lembaga. Mereka bisa melakukan perlindungan untuk kelompoknya dengan jalan memberi keputusan untuk menerima atau menolak calon anggota baru (peminjam baru). Mereka terikat dalam ukbuwah (persaudaraan) tanggung renteng untuk bersama-sama menjadi berdaya dan bersama-sama menanggung resiko pengembalian dana.

Situasi in group yang dinikmati anggota menjadikan mereka menerima program misykat dengan baik. Harapan anggota terhadap misykat dibandingkan kenyataan pelaksanaan misykat relatif sejalan. Anggota relatif taat menjalankan resep pemberdayaan. Partisipasi anggota relatif aktif dalam kelompoknya masing-masing. Penyimpangan program relatif tidak terjadi. Cicilan dan tabungan tiap pekan umumnya lancar. Yang masih ditunggu untuk waktu yang akan datang adalah perubahan sikap mental anggota menjadi mandiri. 
Pengguliran dana di misykat DPU DT cabang Semarang masih pada tahap pertama. Tahap kedua dan ketiga masih menunggu. Kesabaran dan ketelatenan para pengurus dan anggota menjadi kata kunci keberlangsungan dan keberlanjutan misykat. Anggota mengalami masa uji coba selama pembinaan awal. Ia harus sabar untuk benar-benar mendapatkan pinjaman modal. Mereka harus disiplin dalam menbung dan menembalikan pinjaman secara periodik. Manakala hal tersebut terus berjalan niscaya misykat akan berhasil memandirikan pengusaha mikro miskin.

3. Analisa Relasi Misykat dalam Pengentasan Kemiskinan.

Pengentasan kemiskinan memiliki banyak model dan cara. Misykat lebih dekat dengan model grameen bank Muhammad Yunus. Peminjam adalah kelompok yang berpotensi besar untuk berdaya dan berkembang. Sistem yang dipakai mengharuskan anggota memahami tata kerja dan model pengguliran dana misykat. Model tanggung renteng memiliki efek yang baik untuk meningkatkan kinerja anggota sekaligus membangun persaingan sehat anggota. ${ }^{18}$

Program misykat di DPU DT cabang semarang masih permulaan. Belum bisa diukur dengan ukuran kemandirian anggota. Konsistensi anggota melaksanakan serangkaian program miskat adalah ukuran yang bijak untuk melihat peran misykat dalam mengentaskan kemiskinan. Anggota misykat masih sedikit dalam ukuran jumlah. Penyebarannya cukup merata di kodya Semarang. Manfaat yang ditimbulkan ada di beberapa tempat di wilayah tertentu.

Kemanfaatan misykat pada masyarakat ada dua, yaitu: membantu mendanai kebutuhan modal kerja dan membiasakan anggota melakukan usaha yang baik dengan mengefisienkan setiap pendapatan yang dimiliki untuk hidup sederhana, memupuk modal usaha dan tabungan. Program misykat berkaitan erat dengan perbaikan mentalitas para anggota dengan memberikan bimbingan ruhani para anggota. Kegiatan pembinaan ruhani memiliki peran besar dalam langkah pengentasan kemiskinan. Peran kegiatan pembinaan

${ }^{18}$ Muhammad Yunus, Op., Cit., hlm. 119. 
ruhani untuk pengentasan kemiskina inilah yang memberi dorongan kuat anggota untuk mengubah cara pandangnya terhadap kemiskinan. Hal tersebut menjadi pondasi untuk menuntun anggota berusaha meraih rejeki. Model ini adalah bentuk Ijtihad tadbiqi (usaha penerapan ajaran secara tepat guna) pada ajaran zakat yang berdampak besar pada pengentasan kemiskinan.

Hubungan antara misykat dan pengentasan kemiskinan di atas masih kental pada tataran konseptual. Pada tataran bukti-bukti empirik masih menunggu kegiatan selanjutnya. Pengentasan kemiskinan memiliki kompleksitas dan kermitan yang tinggi karena tidak bisa dipecahkan hanya dengan disiplin ilmu ekonomi saja. Dalam banyak hal justru persoalan pemahaman keagamaan terhadap realitas kemiskinan menjadi hal penting yang harus diperhatikan. Jika masyarakat telah berkeyakinan bahwa kemiskinan adalah taqdirnya maka sulit untuk mengajak berusaha keluar dari situasi tersebut. Sebaliknya jika masyarakat menjadi bersemangat berusaha tanda dilandasi dasar agama yang kuat akan menimbulkan masyarakat yang takabur (merasa besar tanpa campur tangan Tuhan). Dua hal tersebut tidak bisa dibenarkan oleh Islam. Dalam melihat misykat satu hal yang patut diberikan catatn adalah seberapa mampukan konsep ajaran misykat tentang usaha dan kemiskinan mampu menyeimbangkan kebutuhan dunyawiyah dan ukhrowiyah dalam pegentasan kemiskinan.

\section{Kesimpulan}

1. Konsep misykat memadukan konsep lembaga keuangan dan dakwah.

2. Anggota misykat memiliki respon seragam karena mereka memiliki rasa in group.

3. Peran misykat dalam pengentasan kemiskinan dalam hal pembiasaan anggota untuk efisien dalam hidup dengan cara menggunakan modal kerja secara efisien, memanfaatkan hasil usaha untuk hari ini dan masa depan, membangun persaingan yang sehat sesama pengusaha. 
Peran Misykat Daarut Taubid dalam Mengentaskan Kemiskinan

\section{DAFTAR PUSTAKA}

Al-Buhari, Jami' al Shabih Bukhari, Juz.1, Dar al-Fikr, t.th

Iwan Rudi Saktiawan, Ir. M.Ag DKK, Panduan Operasional Strategi Pemberdayaan Program Misykat Dompet Peduli Umat Daarut Tauhid, DPU DT Press, Bandung, 2006.

Kompas, Jum'at, 27 juni 2007

Muhammad Yunus, Bank kaum Miskin, terj. Irfan Nasution, Marjin Kiri, Depok, 2007

Nur Fatoni, Zakat, Infaq, dan Shadqah dalam perspektif al-Qur'an, (penelitian dipa fak.Syari'ah 2007)

Taqiyuddin Abu bakar bin Muhammad, Kifayatul Ahyar, Juz.I, Dar al-Ihya' alKutub al-Arabiyah

Q.S. al-Hasr:7

Q.S: 59:7

Saifuddin Zuhri, Drs. M.Ag, Zakat Kontekstual, CV. Bima Sejati, Semarang, 2000

Wawancara dengan Dendi koordiantor misykat DPU DT cabang Semarang, Jumat, 1 Agustus 2008

Wawancara dengan Rantini pembina misykat, ahad, 1 september 2008. 